(c) American Dairy Science Association, 2005.

\title{
Effects of Dietary Cation-Anion Difference on Intake, Milk Yield, and Blood Components of the Early Lactation Cow
}

\author{
P. S. Chan, ${ }^{1}$ J. W. West, ${ }^{1}$ J. K. Bernard, ${ }^{1}$ and J. M. Fernandez ${ }^{2}$ \\ ${ }^{1}$ Department of Animal and Dairy Science, University of Georgia, Coastal Plain Experiment Station, Tifton 31793-0748 \\ ${ }^{2}$ Department of Animal Sciences, Louisiana State University Agricultural Center, Baton Rouge 70803-4210
}

\begin{abstract}
Early lactation Holsteins cows (15 primiparous and 18 multiparous) were offered rations with dietary cation-anion difference, calculated as $\mathrm{mEq}(\mathrm{Na}+\mathrm{K}-\mathrm{Cl}-$ $\mathrm{S}) / 100 \mathrm{~g}$ of feed dry matter (DCAD:S), of 20,35 , or 50 $\mathrm{mEq}$ from d 0 (calving) to $42 \mathrm{~d}$ postpartum (August 20, 2000 to January 9, 2001) to determine the effects of increasing DCAD:S on dry matter intake (DMI), milk yield, and blood metabolites. For DCAD:S of 20, 35, and 50 , DMI was $3.30,3.38,2.96 \mathrm{~kg} / 100 \mathrm{~kg}$ of body weight (BW); milk yield was $25.5,24.2$, and $22.4 \mathrm{~kg} / \mathrm{d}$, respectively. No differences were observed for concentration or yield of milk fat or milk protein. Serum $\mathrm{Ca}, \mathrm{P}, \mathrm{Mg}$, $\mathrm{Na}, \mathrm{K}, \mathrm{Cl}$, cation-anion difference, insulin, and glucose did not differ with DCAD. Serum $\mathrm{HCO}_{3}{ }^{-}$was 26.07, 25.88, and $27.64 \mathrm{mEq} / \mathrm{L}$ for 20,35 , and 50 DCAD:S. Serum $\mathrm{Ca}, \mathrm{Mg}, \mathrm{Na}$, and $\mathrm{K}$ concentrations were greater for primiparous cows $(9.52 \mathrm{mg} / \mathrm{dL}, 2.35 \mathrm{mg} / \mathrm{dL}, 140.03$ $\mathrm{mEq} / \mathrm{L}, 4.66 \mathrm{mEq} / \mathrm{L}$, respectively) than for multiparous cows $(9.27 \mathrm{mg} / \mathrm{dL}, 2.12 \mathrm{mg} / \mathrm{dL}, 137.63 \mathrm{mEq} / \mathrm{L}, 4.46 \mathrm{mEq} /$ $\mathrm{L}$, respectively). A DCAD:S between 23 and $33 \mathrm{mEq} /$ $100 \mathrm{~g}$ of dry matter (DM) appears to be adequate during cool weather for the milk yield that occurred in the present study based on DMI (kg/100 kg of BW), whereas DCAD:S of $50 \mathrm{mEq} / 100 \mathrm{~g}$ of DM may be excessive and could be too alkaline or unpalatable, resulting in decreased DMI (kg/100 kg of BW).
\end{abstract}

(Key words: dietary cation-anion difference, lactation, dry matter intake, milk yield)

Abbreviation key: CAD = cation-anion difference, DCAD = dietary cation-anion difference, $\mathrm{mEq}(\mathrm{Na}+\mathrm{K}$ - Cl) per $100 \mathrm{~g}$ of DM, DCAD:S = dietary cation-anion difference, $\mathrm{mEq}(\mathrm{Na}+\mathrm{K}-\mathrm{Cl}-\mathrm{S})$ per $100 \mathrm{~g}$ of $\mathrm{DM}$.

\section{INTRODUCTION}

Sodium, potassium, and chloride play important roles in maintaining osmotic pressure and acid-base homeo-

Received April 1, 2005.

Accepted July 18, 2005.

Corresponding author: Joe W. West; e-mail: joewest@uga.edu. stasis as well as in enzyme and nerve function. Dietary cation-anion difference may be a superior measure of the effects of electrolytes than the concentration of individual electrolytes provided there are no deficiencies or toxicities present. Dietary cation-anion difference has been defined by several equations, including $\mathrm{mEq}(\mathrm{Na}$ $+\mathrm{K}-\mathrm{Cl}-\mathrm{S})$ per $100 \mathrm{~g}$ of DM (DCAD:S) and mEq (Na $+\mathrm{K}-\mathrm{Cl}$ ) per $100 \mathrm{~g}$ of DM (DCAD). The DCAD for lactating cows was determined to be more important than individual ingredients (Delaquis and Block, 1995b), cation source (West et al., 1992), or individual electrolyte concentrations (Tucker and Hogue, 1990); and increasing DCAD improved milk yield (Tucker et al., 1988a; Block, 1994). Early lactation cows are often in negative energy balance (Bauman and Currie, 1980) and may be more susceptible to metabolic acidosis because of the high concentrate diets fed to meet nutrient needs for lactation. Heat stress, which is often accompanied by a respiratory alkalosis, may also cause a slight metabolic acidosis as a compensatory response (Schneider et al., 1988).

Higher dietary $\mathrm{Na}$ and $\mathrm{K}$ concentrations increase the alkalinity of body fluids. The effect of DCAD is mediated through a change in acid-base chemistry (Block, 1984) and increasing DCAD negates a physiologic acidosis by raising buffering capacity of the blood, reflected by increased blood $\mathrm{pH}$ and blood bicarbonate $\left(\mathrm{HCO}_{3}^{-}\right)$concentration. Blood $\mathrm{pH}$ and $\mathrm{HCO}_{3}{ }^{-}$concentration increased linearly as DCAD:S increased from -10 to 20 $\mathrm{mEq}(\mathrm{Na}+\mathrm{K}-\mathrm{Cl}-\mathrm{S}) / 100 \mathrm{~g}$ of DM, whereas DMI and milk yield improved by 11 and $9 \%$, respectively, for DCAD of 20 vs. -10 (Tucker et al., 1988a). Increasing DMI paralleled a linear increase in blood $\mathrm{pH}$ for cows fed rations with DCAD ranging from 12 to $46 \mathrm{mEq}(\mathrm{Na}$ $+\mathrm{K}-\mathrm{Cl}$ )/100 g of DM (West et al., 1992). Blood $\mathrm{HCO}_{3}{ }^{-}$ increased from 19 to $28 \mathrm{mEq} / \mathrm{L}$ with DCAD:S ranging from 18 to $52 \mathrm{mEq}(\mathrm{Na}+\mathrm{K}-\mathrm{Cl}-\mathrm{S}) / 100 \mathrm{~g}$ of $\mathrm{DM}$, and DMI increased from 20.5 to $24.9 \mathrm{~kg} / \mathrm{d}$ (E. Block, Arm and Hammer Animal Nutrition, personal communication).

Cows exposed to hot weather also benefit from greater DCAD (Escobosa et al., 1984; West et al., 1991, 1992). Blood $\mathrm{HCO}_{3}{ }^{-}$was maximized with DCAD of $38 \mathrm{mEq}$ $(\mathrm{Na}+\mathrm{K}-\mathrm{Cl}) / 100 \mathrm{~g}$ of $\mathrm{DM}$, whereas DCAD ranging from 17 to 38 and 25 to $40 \mathrm{mEq} / 100 \mathrm{~g}$ of DM maximized 
DMI and milk yield, respectively (Sanchez et al., 1994). Intake improved quadratically and milk yield improved linearly as DCAD increased from -12 to $31 \mathrm{mEq}$ (West et al., 1991). These 2 studies implied that a higher DCAD may be required to support milk yield than for DMI. Cows in different stages of lactation may benefit from differing DCAD (Delaquis and Block, 1995a). Blood $\mathrm{pH}$ and $\mathrm{HCO}_{3}{ }^{-}$concentration became more alkaline as the cow progressed from early to late lactation (Erdman et al., 1982).

The optimal DCAD for prepartum dairy cows is negative (in the range of -5 to $-10 \mathrm{mEq} / 100 \mathrm{~g}$ of $\mathrm{DM}$ ), is relatively well defined, reduces the incidence of milk fever; and its effectiveness can be monitored via urine $\mathrm{pH}$ (Horst et al., 1997). A positive DCAD improved ADG in poultry (Mongin, 1981; Hulan et al., 1987) and swine (Patience et al., 1987). When numerous lactation studies were summarized to determine the response to DCAD in terms of DMI and milk yield definite trends were discovered, but the range within which a desirable response was elicited was relatively broad ( $\mathrm{Hu}$ and Murphy, 2004; Sanchez et al., 1994). Thus, the optimal DCAD for lactating dairy cows has not been well defined, responses may differ depending on climatic conditions (cool or hot weather), and there are few data examining the response of dairy cows to DCAD immediately postpartum. The objectives of this trial were to determine the effects of increasing DCAD:S on DMI, milk yield, milk composition, serum electrolytes, and acidbase chemistry, and thus, to elucidate the optimal $\mathrm{DCAD}: \mathrm{S}$ for the early lactation cow during moderately cool weather.

\section{MATERIALS AND METHODS}

\section{Cows and General Management}

Thirty-three Holstein cows (15 primiparous and 18 multiparous) entered the study at parturition. The study began on August 20, 2000, and ended on January 9,2001 . Cows were in the study from calving through $42 \mathrm{~d}$ postpartum. Cows were blocked into groups of 3 according to their 305-d mature equivalent milk for the previous lactation (multiparous cows) or estimated transmitting ability (primiparous cows). Cows were housed and fed in a barn with individual free stalls, a high metal roof, and open ridge vent, with fans and a high pressure misting system for cow cooling. Cows were trained to use electronic gate feeders (American Calan, Northwood, NH) before calving. Cows within blocks were assigned randomly to 1 of 3 treatments: DCAD:S of 20,35 , or $50 \mathrm{mEq}(\mathrm{Na}+\mathrm{K}-\mathrm{Cl}-\mathrm{S}) / 100 \mathrm{~g}$ of DM.

The DCAD:S was formulated using sodium sesquicarbonate and potassium carbonate (K-Minus, Church and
Dwight Co., Inc., Princeton, NJ). Composition of experimental diets is given in Table 1. Cows were fed a TMR once daily $(1300 \mathrm{~h})$ to provide approximately $10 \%$ orts for ad libitum consumption. Orts were removed daily, weighed, and daily feed intake was calculated. Ingredient proportions were adjusted for DM content each week. Cows were milked daily at approximately 0400 and $1500 \mathrm{~h}$. Milk yield was recorded at each milking from day of calving through $42 \mathrm{~d}$ postpartum. Immediately following calving, milk was manually weighed in a bucket and yield was recorded. After colostrum cleared, milk yield was weighed by electronic meter (Alpro, Alfa Laval Agri, St. Louis, MO). Health-related incidents were recorded and cows were treated according to symptoms.

\section{Sampling}

Dietary ingredients and TMR were sampled weekly, dried in a forced-air oven at $60^{\circ} \mathrm{C}$ for $72 \mathrm{~h}$, and $\mathrm{DM}$ content of TMR was used to calculate DMI for the week. Dried samples were ground to pass through a $6-\mathrm{mm}$ screen using a Wiley mill (Arthur Thomas, Philadelphia, PA), labeled, and stored in sealed plastic bags. To improve grinding, whole cottonseed samples were frozen before and after grinding. Samples were composited for 3-wk intervals, ground to pass through a 1-mm screen using a Wiley mill, and stored for later analysis.

Cows were weighed once each week for the duration of the study. Weighing was conducted immediately following the p.m. milking and before cows had access to feed and water. Milk samples were collected each week from 2 consecutive milkings. Blood was collected in evacuated tubes via jugular venipuncture at $1400 \mathrm{~h}$ during wk 2 and 6 postpartum and placed on ice immediately following collection. Serum was harvested from blood samples and frozen for later determination of insulin and glucose.

\section{Analyses}

The DM content of feed ingredients and TMR was determined according to AOAC (1984). Feed N and S were determined (Leco Corporation, St. Joseph, MI) and $\mathrm{CP}$ was calculated as percentage $\mathrm{N} \times 6.25$. Determination of ADF was by AOAC (1990) and NDF was by the method of Van Soest et al. (1991). The concentrations of $\mathrm{Na}, \mathrm{K}, \mathrm{Ca}$, and $\mathrm{Mg}$ were measured by atomic absorption spectrophotometry (model 3030, Perkin-Elmer, Norwalk, CT) following acid digestion (AOAC, 1984). Phosphorus was determined colorimetrically using a Beckman DU-60 spectrophotometer (Beckman Instruments Inc., Fullerton, CA; AOAC, 1984). Chloride was extracted with a combination of acetic acid and nitric 
Table 1. Ingredients and composition of experimental diets.

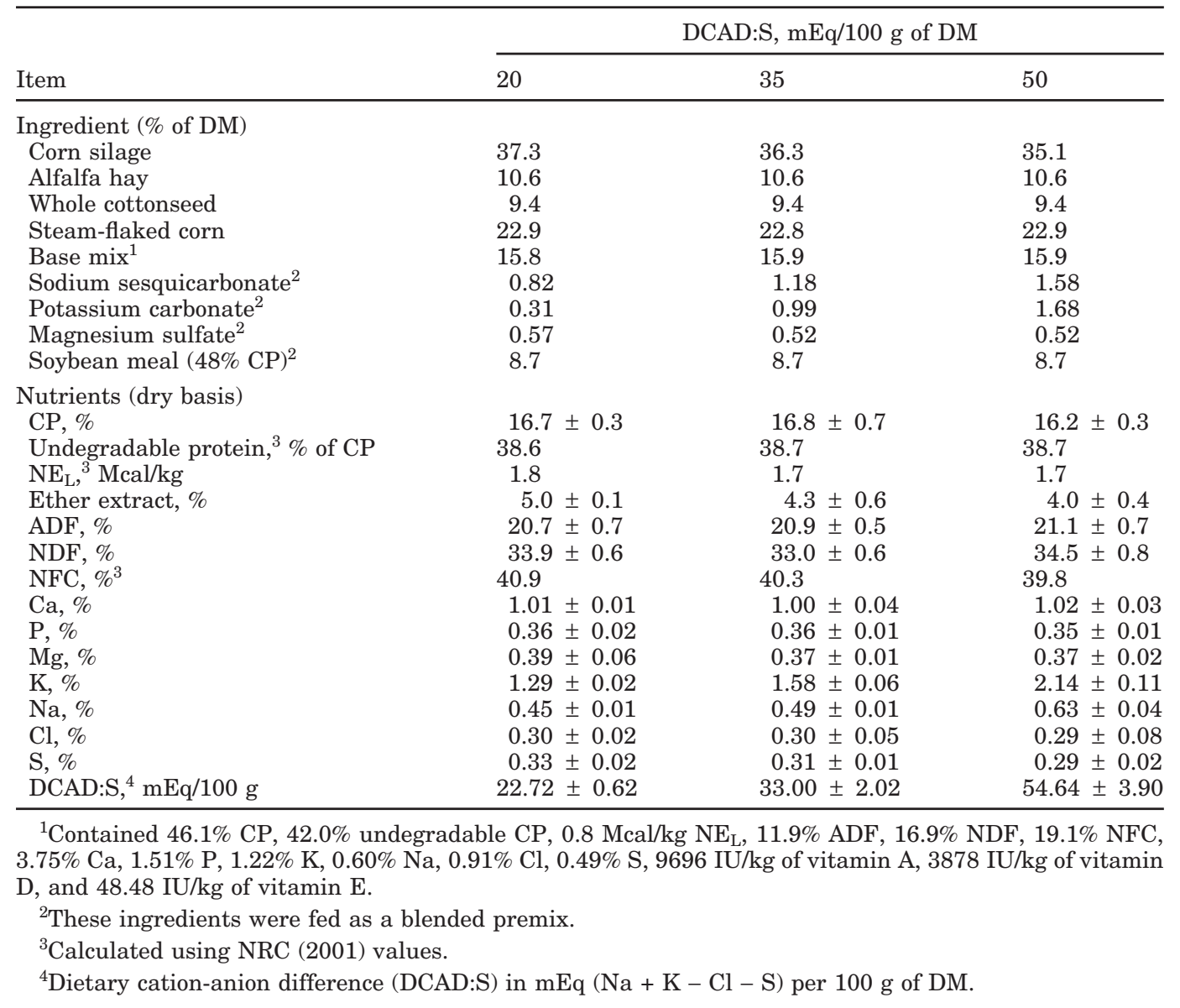

acid and was measured using a chloridometer (Haake Buchler Instruments, Inc., Saddle Brook, NJ) by the method of Cotlove et al. (1958). Ration and ingredient fat content was determined by ether extraction (Soxtec System HT6, Tecator, Hoganas, Sweden; AOAC, 1984). Milk samples were analyzed (Southeast DHIA Laboratory, McDonough, GA) for fat and protein concentration by infrared analysis (Multispec; Foss Electric, Hillerød, Denmark). Blood serum was analyzed at the University of Georgia Veterinary Diagnostic Laboratory in Tifton for $\mathrm{Na}, \mathrm{K}, \mathrm{Cl}, \mathrm{Ca}, \mathrm{P}, \mathrm{Mg}, \mathrm{HCO}_{3}^{-}$(Roche-Hitachi 912, Hoffmann-LaRoche Inc., Indianapolis, IN), and cationanion difference (CAD) was calculated using the equation $\mathrm{mEq}(\mathrm{Na}+\mathrm{K}-\mathrm{Cl}) / \mathrm{mL}$. Serum insulin was determined by radioimmunoassay as described by Bunting et al. (1994). Serum glucose was determined spectrophotometrically using a commercial kit (Tech. Bull. 315, Sigma Chemical, St. Louis, MO).

\section{Statistical Analyses}

Data were analyzed using the MIXED procedure of SAS (SAS Institute, 2001). Analysis of variance was conducted for a replicated randomized complete block design with 3 treatments. The model was:

$$
\begin{aligned}
& \mathrm{Y}_{\mathrm{ijkl}}=\mu+\operatorname{trt}_{\mathrm{i}}+\mathrm{wk}_{\mathrm{j}}+\operatorname{par}_{\mathrm{k}}+\operatorname{blk}_{\mathrm{l}}+\left(\operatorname{trt}_{\mathrm{i}} \times \mathrm{wk}_{\mathrm{j}}\right) \\
& +\left(\mathrm{wk}_{\mathrm{j}} \times \operatorname{par}_{\mathrm{k}}\right)+\left(\operatorname{par}_{\mathrm{k}} \times \operatorname{blk}_{\mathrm{l}}\right)+\left(\operatorname{trt}_{\mathrm{i}} \times \operatorname{par}_{\mathrm{k}}\right) \\
& +\left(\operatorname{trt}_{\mathrm{i}} \times \operatorname{blk}_{\mathrm{l}}\right)+\left(\mathrm{wk}_{\mathrm{j}} \times \operatorname{blk}_{\mathrm{l}}\right)+\left(\operatorname{trt}_{\mathrm{i}} \times \mathrm{wk}_{\mathrm{j}} \times \operatorname{par}_{\mathrm{k}}\right) \\
& +\left(\mathrm{wk}_{\mathrm{j}} \times \operatorname{par}_{\mathrm{k}} \times \mathrm{blk}_{\mathrm{l}}\right)+\left(\operatorname{trt}_{\mathrm{i}} \times \operatorname{par}_{\mathrm{k}} \times \mathrm{blk}_{\mathrm{l}}\right)+\varepsilon_{\mathrm{ijkl}}
\end{aligned}
$$

where $\mu=$ the mean intercept, $\operatorname{trt}_{\mathrm{i}}=$ the effect due to treatment $\mathrm{i}, \mathrm{wk}_{\mathrm{j}}=$ the effect due to $\mathrm{wk} \mathrm{j}, \operatorname{par}_{\mathrm{k}}=$ the effect due to parity $\mathrm{k}, \mathrm{blk}_{\mathrm{l}}=$ the effect due to block $\mathrm{l}$, and $\varepsilon=$ error associated with each $\mathrm{Y}_{\mathrm{ijkl}}$.

Cow within treatment was included as a random effect and week was included as a repeated variable. Significance was declared at $P<0.05$ unless stated otherwise. Treatment effects were compared using the multiple comparisons approach of Tukey (SAS Institute, 2001). Regression analyses were conducted with the Proc REG procedure, whereas correlation coefficients were obtained from the Proc CORR procedure of SAS (2001). 
Table 2. Least square means of production measures for early lactation cows offered DCAD:S of 20,35 , or $50 \mathrm{mEq}(\mathrm{Na}+\mathrm{K}-\mathrm{Cl}-\mathrm{S})$ per $100 \mathrm{~g}$ of DM.

\begin{tabular}{|c|c|c|c|c|c|c|c|c|c|c|c|}
\hline \multirow[b]{3}{*}{ Variable } & \multirow{2}{*}{\multicolumn{3}{|c|}{ DCAD:S, ${ }^{1} \mathrm{mEq} / 100 \mathrm{~g}$ DM }} & \multirow[b]{3}{*}{ SEM } & \multirow{2}{*}{\multicolumn{2}{|c|}{ Parity $^{2}$}} & \multirow[b]{3}{*}{ SEM } & \multicolumn{4}{|c|}{$P^{3}$} \\
\hline & & & & & & & & & & Trt $x$ & $\operatorname{Trt} x$ \\
\hline & 20 & 35 & 50 & & 1 & $>1$ & & Trt & Par & Par & Wk \\
\hline DMI, kg/100 kg BW & $3.30^{\mathrm{a}}$ & $3.38^{\mathrm{a}}$ & $2.96^{\mathrm{b}}$ & 0.13 & 3.48 & 2.94 & 0.13 & $*$ & $* *$ & $*$ & NS \\
\hline $\mathrm{BW}, \mathrm{kg}$ & 505 & 509 & 525 & 10 & 456 & 570 & 9 & NS & $* * *$ & NS & $*$ \\
\hline Milk, kg/d & 25.5 & 24.2 & 22.4 & 1.6 & 21.9 & 26.1 & 1.3 & NS & $*$ & $\dagger$ & NS \\
\hline $3.5 \% \mathrm{FCM}, \mathrm{kg} / \mathrm{d}$ & 27.8 & 25.6 & 25.7 & 2.4 & 23.6 & 29.1 & 2.0 & NS & * & NS & NS \\
\hline Fat, kg & 1.05 & 1.05 & 1.05 & 0.17 & 0.92 & 1.18 & 0.10 & NS & $\dagger$ & NS & NS \\
\hline Protein, kg & 0.74 & 0.78 & 0.69 & 0.05 & 0.65 & 0.82 & 0.04 & NS & $* *$ & NS & NS \\
\hline
\end{tabular}

${ }^{\mathrm{a}, \mathrm{b}}$ Means within a row with different superscripts are different $(P<0.05)$.

${ }^{1}$ Represents dietary cation-anion difference (DCAD:S) $(\mathrm{Na}+\mathrm{K}-\mathrm{Cl}-\mathrm{S})$.

${ }^{2} 1$ represents primiparous cows and $>1$ represents multiparous cows.

${ }^{3}$ Trt $=$ Treatment; Par $=$ Parity.

$\dagger P<0.10 ; * P<0.05 ; * * P<0.01 ; * * * P<0.0001$.

\section{RESULTS AND DISCUSSION}

\section{Intake and BW}

There were no differences in DMI $(\mathrm{kg} / \mathrm{d})$ related to DCAD:S but the DMI $(\mathrm{kg} / 100 \mathrm{~kg}$ of BW) was greater $(P<0.05)$ for diets with DCAD:S of 20 and 35 compared with the 50 DCAD:S treatment (Table 2). The latter treatment (50 DCAD:S) is equivalent to $73 \mathrm{mEq} / 100 \mathrm{~g}$ of DM DCAD (S excluded from the equation) and may have caused palatability problems or excess alkalinity, reducing DMI. Reduced palatability with cationic salts resulted in depressed feed intake (Stokes et al., 1986). There was a treatment by parity interaction $(P<0.05)$ for DMI (kg/100 kg of BW). Intake for primiparous cows $(3.83 \mathrm{~kg} / 100 \mathrm{~kg}$ of BW) was greater than that for multiparous cows (2.78 kg/100 kg of BW) at 20 DCAD:S, which was greater than for primiparous and multiparous cows consuming 35 DCAD:S (3.43 and $3.32 \mathrm{~kg} / 100 \mathrm{~kg}$ of BW, respectively) and 50 DCAD:S (3.19 and $2.73 \mathrm{~kg} / 100 \mathrm{~kg}$ of BW, respectively) treatments. Intake per $100 \mathrm{~kg}$ of BW for primiparous cows was consistently greater than for multiparous cows. West et al. (1992) reported that DMI increased linearly when lactating cows received DCAD treatments ranging from 12 to $46 \mathrm{mEq} / 100 \mathrm{~g}$ of DM during hot weather. In the present study, 20 and 35 DCAD:S were equivalent to DCAD of 43 and $52 \mathrm{mEq}$ $(\mathrm{Na}+\mathrm{K}-\mathrm{Cl}) / 100 \mathrm{~g}$ of DM.

Our findings are consistent with work by Roche et al. (2003), which demonstrated that a DCAD:S above $52 \mathrm{mEq} / 100 \mathrm{~g}$ was detrimental to feed intake. Cows offered the 50 DCAD:S treatment in the present study were actually consuming approximately $55 \mathrm{mEq} / 100 \mathrm{~g}$ of DCAD:S (Table 1). The DCAD equation without $\mathrm{S}$ was typically used in earlier studies with lactating cows and the very high level of DCAD used in the present study is not common in the literature. The DCAD concentrations used by Tucker et al. (1988b) are comparable with this study; however, only plasma minerals were measured and feed intake and milk yield were not reported in the Tucker study.

Sanchez et al. (1994) reported a DCAD range from 12 to $62 \mathrm{mEq} / 100 \mathrm{~g}$ of DM and observed optimal DMI for midlactation cows when DCAD was between 30 and $50 \mathrm{mEq} / 100 \mathrm{~g}$ of DM. Results for the present study are in agreement with this range, in which DMI was numerically higher for 20 and 35 DCAD:S (equivalent to 43 and $52 \mathrm{mEq} / 100 \mathrm{~g}$ of $\mathrm{DM} \mathrm{Na}+\mathrm{K}-\mathrm{Cl}$ ) than for 50 DCAD:S. Although the 35 DCAD:S diet is slightly beyond the optimal range suggested by Sanchez et al. (1994), the present study was conducted with early lactation cows rather than midlactation cows. Early lactation cows may require a higher DCAD than cows in later lactation (Delaquis and Block, 1995a).

\section{Milk Yield and Milk Composition}

The DCAD:S did not affect milk yield or milk composition (Table 2), consistent with reports by Roche et al. (2003). Milk yield is dependent on DMI (Kertz et al., 1991), and in the present study, regression of milk yield on DMI yielded the model $\mathrm{y}=4.19+1.31 \mathrm{x}$, where $\mathrm{y}$ is milk yield $(\mathrm{kg} / \mathrm{d})$ and $\mathrm{x}$ is DMI $(\mathrm{kg} / \mathrm{d})\left(\mathrm{R}^{2}=0.54, P<\right.$ 0.0001). Lower DMI (kg/100 kg of BW) for 50 DCAD:S was accompanied by numerically lower milk yield compared with 20 and 35 DCAD:S. When DCAD is calculated without $\mathrm{S}$ in the equation, the $50 \mathrm{DCAD}: \mathrm{S}$ treatment is equivalent to $73 \mathrm{mEq}(\mathrm{Na}+\mathrm{K}-\mathrm{Cl}) / 100 \mathrm{~g}$ of DM. Sanchez and Beede (1996) reported that performance was compromised when DCAD was over $50 \mathrm{mEq} /$ $100 \mathrm{~g}$ of DM. In contrast, Block (E. Block, Arm and 
Hammer Animal Nutrition, personal communication) reported improved milk yield up to DCAD:S of $52 \mathrm{mEq} /$ $100 \mathrm{~g}$ of DM in a cool-weather study. West et al. (1991) reported linear increases in milk yield when DCAD was increased from -12 to $31 \mathrm{mEq} / 100 \mathrm{~g}$ of DM. Both milk yield and $3.5 \%$ FCM yield exhibited a parity effect $(P$ $<0.05$ ), in which production of mature cows was greater than for primiparous cows (Table 2).

Milk yield and DMI were moderate for the present study (Table 2). Because of the level of DMI, subsequent ruminal fermentation and organic acid production would be expected to be similarly moderate. It is plausible that cows with a higher intake of fermentable carbohydrates would benefit from a higher DCAD concentration. A meta-analysis conducted by $\mathrm{Hu}$ and Murphy (2004) demonstrated a quadratic milk yield response to increasing DCAD. The optimum range was broad, ranging from approximately 25 to $40 \mathrm{mEq} / 100 \mathrm{~g}$ of DM but average milk yield peaked at about $24 \mathrm{~kg} / \mathrm{d}$. Similarly, DMI peaked near $20 \mathrm{~kg} / \mathrm{d}$ (again moderate), while blood $\mathrm{pH}$ and $\mathrm{HCO}_{3}{ }^{-}$concentration followed patterns similar to DMI (Hu and Murphy, 2004). Sanchez et al. (1994) reported a similar range of DMI and milk yield response to DCAD, and milk yield peaked at about 22 $\mathrm{kg} / \mathrm{d}$. In a summary of dietary buffer studies, Erdman (1988) reported that cows were responsive to sodium bicarbonate supplementation at approximately $30 \mathrm{~kg} /$ $\mathrm{d}$ milk yield for corn silage-based diets, but were less responsive when alfalfa and grass hays and silages were fed. Diets supplemented with sodium bicarbonate would have a greater DCAD value, whereas the diets containing alfalfa and grass hay and silage would have higher initial DCAD values and would be expected to be less responsive to greater cation content in the diet. Roche et al. (2003) used a wide DCAD range that extended to very high DCAD values $(+21,+52,+102$, and $+127 \mathrm{mEq} / 100 \mathrm{~g}$ of $\mathrm{DM})$. Those authors reported no improvement in milk yield, a small but linear decline in DMI, and a reduced daily weight gain with the relatively high and increasing DCAD. Reported milk yield was in the range of 23.2 to $25.4 \mathrm{~kg} / \mathrm{d}$ and DMI varied around $15 \mathrm{~kg} / \mathrm{d}$, and was perhaps inadequate to challenge the systemic buffering capacity of the cow. Further DCAD research with high-producing dairy cows will be necessary to define the range necessary to provide ruminal and systemic buffering for cows consuming large quantities of DM.

Milk fat and protein percentage and yield were not affected by DCAD (Table 2), agreeing with West et al. (1992) and Delaquis and Block (1995a). Milk fat percentage was relatively high, probably reflecting mobilized adipose tissue in early lactation. Milk yield and milk protein percentage and yield for early lactation cows were not changed by sodium sesquicarbonate sup- plementation (Cassida et al., 1988). Multiparous cows yielded greater fat and protein than primiparous cows due primarily to greater milk yield. Milk protein yield was positively correlated with DMI $\left(\mathrm{R}^{2}=0.56, P<\right.$ 0.0001).

\section{Serum Metabolites}

Serum $\mathrm{HCO}_{3}{ }^{-}$was numerically higher for the 50 DCAD:S treatment (Table 3) although statistically, the 20 DCAD:S diet was similar $(P<0.10)$. Tucker et al. (1988b) reported that serum $\mathrm{HCO}_{3}^{-}$was greater for diets containing DCAD:S of 55 vs. $48 \mathrm{mEq} / 100 \mathrm{~g}$ of DM. The 50 DCAD:S diet in the present study may have been excessively alkaline as reflected by serum $\mathrm{HCO}_{3}{ }^{-}$ $(27.6 \mathrm{mEq} / \mathrm{L})$, which was at the high end of the physiological range (21.5 to $27.7 \mathrm{mEq} / \mathrm{L}$ ) described by Benjamin (1981). An elevation of serum $\mathrm{HCO}_{3}{ }^{-}$may diminish serum $\mathrm{Cl}$ concentration because these anions are balanced and exchanged to maintain electroneutrality (Guyton, 1981). The actual DCAD:S calculated from ration analysis for 50 DCAD:S was $54.6 \mathrm{mEq} / 100 \mathrm{~g}$ of DM, slightly higher than the DCAD:S $52 \mathrm{mEq} / 100 \mathrm{~g}$ of DM used by Block (E. Block, Arm and Hammer Animal Nutrition, personal communication). However, Block reported improved DMI and milk yield even when blood $\mathrm{HCO}_{3}{ }^{-}$was $28 \mathrm{mEq} / \mathrm{L}$ for the $52 \mathrm{mEq}$ DCAD:S diet.

Similarity among serum $\mathrm{HCO}_{3}^{-}$for 20 and 35 DCAD:S treatments paralleled DMI $(\mathrm{kg} / 100 \mathrm{~kg}$ of BW; Table 2. The analyzed DCAD:S for the 20 and 35 DCAD:S treatments were 23 and $33 \mathrm{mEq} / 100 \mathrm{~g}$ of DM, and the range was narrower than anticipated. Diets fed to lactating dairy cows without and with buffer supplementation (DCAD concentrations of 27 and 33 $\mathrm{mEq} / 100 \mathrm{~g}$ of $\mathrm{DM}$, respectively) resulted in no change in feed intake or milk yield (McKinnon et al., 1990). Sanchez et al. (1997) reported no difference for DMI, milk yield, or milk fat composition when DCAD ranged from 25 to $40 \mathrm{mEq} / 100 \mathrm{~g}$ of DM. Reports suggest that DCAD effects are mediated through blood buffering (West et al., 1992; Delaquis and Block, 1995b). The present trial agrees with the hypothesis because DMI (Table 2) and serum $\mathrm{HCO}_{3}{ }^{-}$(Table 3) were the only variables that responded to $\mathrm{DCAD}: \mathrm{S}$. Serum $\mathrm{HCO}_{3}{ }^{-}$declined $(P=0.03)$ from wk 2 to 6 postpartum, possibly due to the increasing DMI over time. Greater consumption of concentrates increases systemic acidity and decreases serum bicarbonate.

A treatment by week interaction occurred for serum insulin (Table 3). The serum insulin concentration for the 35 DCAD:S treatment at wk 2 postpartum was lower $(P<0.10)$ than that for wk 6 postpartum. The reason for this difference is not apparent. However, insulin concentrations are positively correlated with 
Table 3. The effects of DCAD:S on serum metabolites for early lactation cows offered DCAD:S of 20,35 or $50 \mathrm{mEq}(\mathrm{Na}+\mathrm{K}-\mathrm{Cl}-\mathrm{S})$ per 100 g DM.

\begin{tabular}{|c|c|c|c|c|c|c|c|c|c|c|c|c|c|}
\hline \multirow[b]{3}{*}{ Variable } & \multirow[b]{3}{*}{ Week $^{1}$} & \multirow{2}{*}{\multicolumn{4}{|c|}{ DCAD: $\mathrm{S}^{2}, \mathrm{mEq} / 100 \mathrm{~g} \mathrm{DM}$}} & \multirow[b]{3}{*}{ SEM } & \multirow{2}{*}{\multicolumn{2}{|c|}{ Parity $^{3}$}} & \multirow[b]{3}{*}{ SEM } & \multicolumn{4}{|c|}{$P^{4}$} \\
\hline & & & & & & & & & & \multirow[b]{2}{*}{ Trt } & \multirow[b]{2}{*}{ Par } & \multirow{2}{*}{$\begin{array}{l}\text { Trt } \times \\
\text { Par }\end{array}$} & \multirow{2}{*}{$\begin{array}{l}\text { Trt } \times \\
\text { Wk }\end{array}$} \\
\hline & & 20 & 35 & 50 & Mean & & 1 & $>1$ & & & & & \\
\hline $\mathrm{HCO}_{3}^{-}, \mathrm{mEq} / \mathrm{L}$ & 6 & 25.6 & $\begin{array}{l}25.5 \\
25.9^{\mathrm{a}}\end{array}$ & $\begin{array}{l}26.6 \\
276^{\mathrm{b}}\end{array}$ & $25.9^{\mathrm{d}}$ & 0.60 & 2617 & 26.89 & 049 & + & NS & $\mathrm{NS}$ & NS \\
\hline \multirow{2}{*}{ Insulin, $\mu \mathrm{IU} / \mathrm{mL}$} & 2 & 9.4 & 6.0 & 9.8 & $8.4^{\mathrm{c}}$ & .00 & 20.16 & 20.00 & & 1 & & 10 & - \\
\hline & 6 & $\begin{array}{r}5.4 \\
11.1\end{array}$ & 14.1 & 10.2 & $11.8^{\mathrm{d}}$ & & & & & & & & \\
\hline \multirow{2}{*}{ Glucose, mmol/L } & 6 & 3.84 & 3.62 & 3.46 & $3.64^{\mathrm{d}}$ & & & & & & & & \\
\hline & Mean & 3.60 & 3.31 & 3.34 & & 0.14 & 3.39 & 3.44 & 0.11 & NS & NS & NS & NS \\
\hline \multirow[t]{3}{*}{ Serum $\mathrm{CAD},{ }^{5} \mathrm{mEq} / \mathrm{L}$} & 2 & 46.5 & 46.0 & 48.9 & 47.1 & & & & & & & & \\
\hline & & 45.6 & 46.0 & 46.2 & 45.9 & & & & & & & & \\
\hline & Mean & 46.1 & 46.0 & 47.5 & & 0.69 & 46.78 & 46.24 & 0.57 & NS & NS & NS & NS \\
\hline \multicolumn{14}{|c|}{${ }^{1}$ Week $=$ Week relative to parturition $(2)=2 \mathrm{wk}$ postpartum $(6)=6 \mathrm{wk}$ postpartum. } \\
\hline \multicolumn{14}{|c|}{${ }^{3} 1$ represents primiparous cows and $>1$ represents multiparous cows. } \\
\hline \multicolumn{14}{|c|}{${ }^{4}$ Trt $=$ Treatment; Par $=$ Parity } \\
\hline \multicolumn{14}{|c|}{$\begin{array}{l}{ }^{5} \mathrm{CAD}=\text { Cation-anion difference }(\mathrm{Na}+\mathrm{K}-\mathrm{Cl}) \text { in } \mathrm{mEq} / \mathrm{L} \text {. } \\
\dagger P<0.10 \text {. }\end{array}$} \\
\hline
\end{tabular}

energy balance (Arieli et al., 2001), and body reserves are mobilized during negative energy balance (Bauman and Currie, 1980). Rastani et al. (2001) reported that a nadir of tissue energy balance occurred at wk 2 postpartum compared with wk 4 prepartum through wk 17 postpartum. Because serum insulin in the current study was lower for wk $2(8.4 \mu \mathrm{IU} / \mathrm{mL})$ relative to wk $6(11.8 \mu \mathrm{IU} / \mathrm{mL}$ ) postpartum (Table 3), energy balance for cows at wk 2 postpartum was probably more negative than at wk 6 postpartum.

There was no effect of DCAD:S on serum CAD, calculated as $\mathrm{mEq}(\mathrm{Na}+\mathrm{K}-\mathrm{Cl}) / \mathrm{mL}$. However, serum $\mathrm{HCO}_{3}{ }^{-}$ had a significant $(P<0.0001)$ positive relationship with serum CAD (Figure 1). Tucker and Hogue (1990) reported a positive linear relationship between blood $\mathrm{HCO}_{3}{ }^{-}$and serum CAD. Plasma CAD increased significantly from 44 to $49 \mathrm{mEq} / \mathrm{L}$ for cows fed diets with DCAD:S of 9 vs. $22 \mathrm{mEq} / 100 \mathrm{~g}$ of $\mathrm{DM}$ (Tucker et al., 1991). Because DCAD affects blood acid-base chemistry as reflected by serum $\mathrm{CAD}$ and serum $\mathrm{HCO}_{3}{ }^{-}$, nutrient manipulation can be useful in modifying the acid-base chemistry of cows to improve productivity. Serum CAD should be further investigated to determine the optimal concentration for performance enhancement.

No DCAD:S treatment effects were observed for serum mineral concentrations (Table 4). These results agree with previous reports (Tucker et al., 1988a; West et al., 1992; Delaquis and Block, 1995a). Homeostatic mechanisms typically maintain blood $\mathrm{Ca}$ and $\mathrm{P}$ concen- trations within the normal range (Guyton, 1981), and DCAD had no effect on plasma $\mathrm{P}, \mathrm{Mg}, \mathrm{Na}$, and $\mathrm{K}$ in the work by Tucker et al. (1991). In the present study, serum $\mathrm{Mg}$ was greater $(P=0.03)$ for primiparous cows $(2.35 \mathrm{mg} / \mathrm{dL})$ than for mature cows $(2.12 \mathrm{mg} / \mathrm{dL})$ and at wk 6 compared with wk 2 postpartum (Table 4 ), perhaps because of greater DMI (kg/100 kg of BW) for primiparous cows (Table 2) and greater DMI for wk 6 compared with wk 2 postpartum. Serum $\mathrm{Cl}$ concentrations follow serum $\mathrm{Na}$ and $\mathrm{K}$ concentrations because of the need to maintain electroneutrality (Rose, 1984). Regression analyses for serum $\mathrm{Na}$ on $\mathrm{Cl}$ and serum $\mathrm{K}$ on $\mathrm{Cl}$ yielded $\mathrm{R}^{2}$ values of 0.51 and 0.24 , respectively $(P<0.0001)$. A one-unit $(1.0 \mathrm{mEq} / \mathrm{L})$ increase in serum $\mathrm{Cl}$ concentration was accompanied by $0.7 \mathrm{mEq} / \mathrm{L}$ increase in serum $\mathrm{Na}$ and $0.04 \mathrm{mEq} / \mathrm{L}$ increase in serum $\mathrm{K}$. The relationship is stronger with $\mathrm{Na}$ because $\mathrm{Cl}$ is found in the extracellular compartment with $\mathrm{Na}$ (Guyton, 1981). Serum $\mathrm{Cl}$ had a reciprocal relationship with serum $\mathrm{HCO}_{3}{ }^{-}$ ( $\mathrm{r}=-0.55, P<0.0001)$, which has been observed by others (Escobosa et al., 1984; West et al., 1992; Sanchez et al., 1994).

\section{CONCLUSIONS}

The DMI (kg/100 kg of BW) was similar for 20 and 35 DCAD:S treatments, which were greater compared with the 50 DCAD:S treatment. Serum $\mathrm{HCO}_{3}{ }^{-}$tended to be higher for the 50 DCAD:S diet and the concentra- 


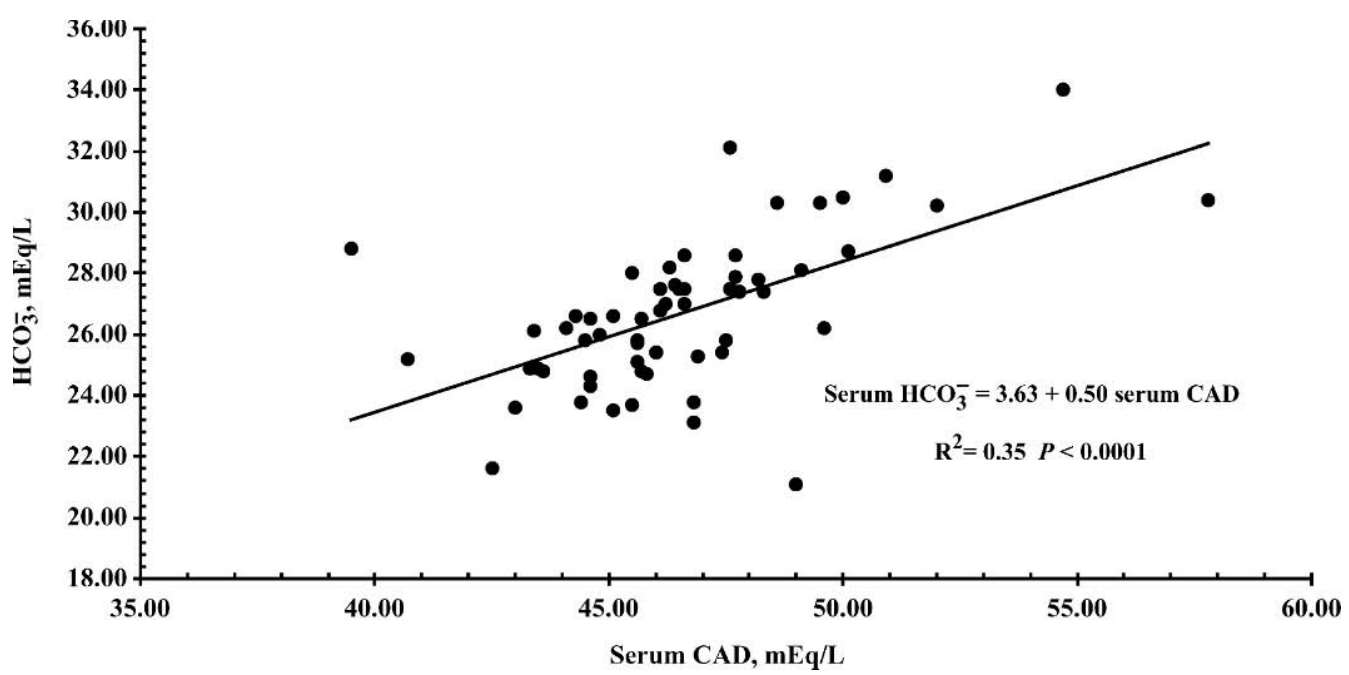

Figure 1. Simple linear regression of serum $\mathrm{HCO}_{3}{ }^{-}$on serum cation-anion difference $(\mathrm{Na}+\mathrm{K}-\mathrm{Cl}$, mEq/L) for cows offered dietary cation-anion difference (DCAD:S) of 20,35 , and $50 \mathrm{mEq}(\mathrm{Na}+\mathrm{K}-\mathrm{Cl}-\mathrm{S}) / 100 \mathrm{~g}$ of DM.

tions of serum $\mathrm{HCO}_{3}^{-}$and $\mathrm{CAD}$ were positively correlated. The 20 and 35 DCAD:S treatments appeared adequate for the early lactation cow during cool weather; 50 DCAD:S may have been too alkaline or was unpalatable. In addition, in the presence of the moderate milk yield and DMI encountered in the present study, the cows' acid-base balance may not have been challenged sufficiently to benefit from the highest DCAD treatment. However, additional work is needed to evaluate the response of high-yielding, early lactation dairy cows

Table 4. The effects of DCAD:S on serum electrolytes for early lactation cows offered DCAD:S of 20,35 , or $50 \mathrm{mEq}(\mathrm{Na}+\mathrm{K}-\mathrm{Cl}-\mathrm{S})$ per $100 \mathrm{~g}$ of DM.

\begin{tabular}{|c|c|c|c|c|c|c|c|c|c|c|c|c|c|}
\hline \multirow[b]{3}{*}{ Variable } & \multirow[b]{3}{*}{ Week $^{1}$} & \multirow{2}{*}{\multicolumn{4}{|c|}{ DCAD:S, ${ }^{2} \mathrm{mEq} / 100 \mathrm{~g} \mathrm{DM}$}} & \multirow[b]{3}{*}{ SEM } & \multirow{2}{*}{\multicolumn{2}{|c|}{ Parity $^{3}$}} & \multirow[b]{3}{*}{ SEM } & \multicolumn{4}{|c|}{$P^{4}$} \\
\hline & & & & & & & & & & \multirow[b]{2}{*}{ Trt } & \multirow[b]{2}{*}{ Par } & \multirow{2}{*}{$\begin{array}{l}\text { Trt } \times \\
\text { Par }\end{array}$} & \multirow{2}{*}{$\begin{array}{l}\text { Trt } \times \\
\text { Wk }\end{array}$} \\
\hline & & 20 & 35 & 50 & Mean & & 1 & $>1$ & & & & & \\
\hline \multirow{2}{*}{$\mathrm{Ca}, \mathrm{mg} / \mathrm{dL}$} & 6 & 9.48 & 9.48 & 9.43 & 9.46 & & & & & & & & \\
\hline & Mean & 9.52 & 9.32 & 9.34 & & 0.11 & 9.52 & 9.27 & 0.09 & NS & $\dagger$ & * & NS \\
\hline \multirow[t]{2}{*}{$\mathrm{P}, \mathrm{mg} / \mathrm{dL}$} & 2 & 6.07 & 6.44 & 5.80 & 6.10 & & & & & & & & \\
\hline & 6 & 6.13 & 6.60 & 6.38 & 6.37 & & & & & & & & \\
\hline \multirow{2}{*}{$\mathrm{Mg}, \mathrm{mg} / \mathrm{dL}$} & 6 & 2.34 & 2.31 & 2.29 & $2.31^{\mathrm{b}}$ & & & & & & & & \\
\hline & Mean & 2.28 & 2.24 & 2.21 & & 0.13 & 2.35 & 2.12 & 0.07 & NS & $*$ & NS & NS \\
\hline \multirow[t]{3}{*}{$\mathrm{Na}, \mathrm{mEq} / \mathrm{L}$} & 2 & 138.8 & 140.1 & 140.7 & $139.9^{\mathrm{a}}$ & & & & & & & & \\
\hline & 6 & 135.6 & 138.9 & 138.8 & $137.8^{\mathrm{b}}$ & & & & & & & & \\
\hline & Mean & 137.2 & 139.5 & 139.8 & & 0.94 & 140.03 & 137.63 & 0.77 & NS & $*$ & NS & NS \\
\hline $\mathrm{K}, \mathrm{mEq} / \mathrm{L}$ & 2 & 4.33 & 4.63 & 4.39 & $4.45^{\mathrm{a}}$ & & & & & & & & \\
\hline $\mathrm{Cl}, \mathrm{mEq} / \mathrm{L}$ & Mean & 95.7 & 98.2 & 96.8 & & 1.14 & 97.91 & 95.86 & 0.93 & NS & NS & NS & NS \\
\hline
\end{tabular}

${ }^{\mathrm{a}, \mathrm{b}}$ Means within column for each variable with different superscripts are different $(P<0.05)$.

${ }^{1}$ Week $=$ Week relative to parturition $(2)=2 \mathrm{wk}$ postpartum $(6)=6 \mathrm{wk}$ postpartum .

${ }^{2}$ Represents dietary cation-anion difference $(\mathrm{Na}+\mathrm{K}-\mathrm{Cl}-\mathrm{S})$.

${ }^{3} 1$ represents primiparous cows and $>1$ represents multiparous cows.

${ }^{4}$ Trt $=$ Treatment; Par $=$ Parity.

$\dagger P<0.10 ; * P<0.05$. 
to DCAD to better define both the DCAD range and the benefits to cows consuming very high levels of feed DM, and for high-producing cows exposed to hot weather. The DCAD:S may be a better measure of macromineral requirements rather than individual concentrations, and further studies using DCAD:S in early lactation cows should categorize serum CAD as it correlates with serum bicarbonate in cool and hot weather, because blood bicarbonate can be influenced by environment. There may be an optimal serum $\mathrm{CAD}$ or $\mathrm{HCO}_{3}{ }^{-}$concentration for the lactating dairy cow.

\section{ACKNOWLEDGMENTS}

The Church and Dwight Company, Inc. is gratefully acknowledged for furnishing sodium sesquicarbonate and potassium carbonate used in the trial. The authors would like to thank Sue Trammell, Heath Cross, Cameron Asbell, Cal Williamson, student workers, and employees from the University of Georgia Dairy Research Center in Tifton for help in feeding and caring for cows on the trial. Gratitude also goes to Anita Merrill from the University of Georgia Veterinary Diagnostic Laboratory for blood analyses.

\section{REFERENCES}

AOAC. 1984. Official Methods of Analysis. I. 14th ed. Association of Official Analytical Chemists International, Arlington, VA.

Arieli, A., S. Abramson, S. J. Mabjeesh, S. Zamwel, and I. Bruckental. 2001. Effect of site and source of energy supplementation on milk yield in dairy cows. J. Dairy Sci. 84:462-470.

Bauman, D. E., and W. B. Currie. 1980. Partitioning of nutrients during pregnancy and lactation: A review of mechanisms involving homeostasis and homeorhesis metabolism of dairy cows. J. Dairy Sci. 63:1514-1529.

Benjamin, M. M. 1981. Fluid and electrolytes. Page 213 in Outline of Veterinary Clinical Pathology. Iowa State Univ. Press, Ames.

Block, E. 1984. Manipulating dietary anions and cations for prepartum dairy cows to reduce incidence of milk fever. J. Dairy Sci. 67:2939-2948.

Block, E. 1994. Manipulation of dietary cation-anion difference on nutritionally related production diseases, productivity, and metabolic responses of dairy cows. J. Dairy Sci. 77:1437-1450.

Bunting, L. D., J. M. Fernandez, D. L. Thompson, Jr., and L. L. Southern. 1994. Influence of chromium picolinate on glucose usage and metabolic criteria in growing Holstein calves. J. Anim. Sci. 72:1591-1599.

Cassida, K. A., L. D. Muller, and T. F. Sweeney. 1988. Sodium sesquicarbonate for early lactation dairy cows fed corn silage-based diets. J. Dairy Sci. 71:381-387.

Cotlove, E. H., H. V. Trantham, and R. L. Bowman. 1958. An instrument and method for automatic, accurate, and sensitive titration of chloride in biological samples. J. Lab. Clin. Med. 51:461-465.

Delaquis, A. M., and E. Block. 1995a. Dietary cation-anion difference, acid-base status, mineral metabolism, renal function and milk production of lactating cows. J. Dairy Sci. 78:2259-2284.

Delaquis, A. M., and E. Block. 1995b. The effects of changing ration ingredients on acid-base status, renal function, and macromineral metabolism. J. Dairy Sci. 78:2024-2039.

Erdman, R. A. 1988. Dietary buffering requirements of the lactating dairy cow: A review. J. Dairy Sci. 71:3246-3266.

Erdman, R. A., R. W. Hemken, and L. S. Bull. 1982. Dietary sodium bicarbonate and magnesium oxide for early postpartum lactating dairy cows: Effects on production, acid-base metabolism and digestion. J. Dairy Sci. 65:712-731.

Escobosa, A., C. E. Coppock, L. D. Rowe, Jr., W. L. Jenkins, and C. E. Gates. 1984. Effects of dietary sodium bicarbonate and calcium chloride on physiological responses of lactating dairy cows in hot weather. J. Dairy Sci. 67:574-584.

Guyton, A. C. 1981. Textbook of Medical Physiology. W. B. Saunders Co., Philadelphia, PA.

Horst, R. L., J. P. Goff, T. A. Reinhardt, and D. R. Buxton. 1997. Strategies for preventing milk fever in dairy cattle. J. Dairy Sci. 80:1269-1280.

Hu, W., and M. R. Murphy. 2004. Dietary cation-anion difference effects on performance and acid-base status of lactating dairy cows: A meta-analysis. J. Dairy Sci. 87:2222-2229.

Hulan, H. W., P. C. M. Simons, P. J. W. Van Schagen, K. B. McRae, and F. G. Proudfoot. 1987. Effect of dietary cation-anion balance and calcium content on general performance and incidence of leg abnormalities of broiler chickens. Can. J. Anim. Sci. 67:165-177.

Kertz, A. F., L. F. Reutzel, and G. M. Thomson. 1991. Dry matter intake from parturition to midlactation. J. Dairy Sci. 74:22902295

McKinnon, J. J., D. A. Christensen, and B. Laarveld. 1990. The influence of bicarbonate buffers on milk production and acid-base balance in lactating dairy cows. Can. J. Anim. Sci. 70:875-886.

Mongin, P. 1981. Recent advances in dietary cation-anion balance: applications in poultry. Proc. Nutr. Soc. 40:285-294.

National Research Council. 2001. Nutrient Requirements of Dairy Cattle. 7th rev. ed. Natl. Acad. Sci., Washington, DC.

Patience, J. F., R. E. Austic, and R. D. Boyd. 1987. Effect of dietary electrolyte balance on growth and acid-base status in swine. J. Anim. Sci. 64:457-466.

Rastani, R. R., S. M. Andrew, S. A. Zinn, and C. J. Sniffen. 2001. Body composition and estimated energy balance in Jersey and Holstein cows during early lactation. J. Dairy Sci. 84:1201-1209.

Roche, J. R., D. Dalley, P. Moate, C. Grainger, M. Rath, and F. O'Mara. 2003. Dietary cation-anion difference and the health and production of pasture-fed dairy cows. 1. Dairy cows in early lactation. J. Dairy Sci. 86:970-978.

Rose, B. D. 1984. Clinical Physiology of Acid-Base and Electrolyte Disorders. 2nd ed. McGraw-Hill Book Co., New York, NY.

Sanchez, W. K., and D. K. Beede. 1996. Is there an optimal cationanion difference for lactation diets? Anim. Feed Sci. Technol. 59:3-12.

Sanchez, W. K., D. K. Beede, and J. A. Cornell. 1994. Interactions of sodium, potassium and chloride on lactation, acid-base status and mineral concentrations. J. Dairy Sci. 77:1661-1675.

Sanchez, W. K., D. K. Beede, and J. A. Cornell. 1997. Dietary mixtures of sodium bicarbonate, sodium chloride, and potassium chloride: Effects on lactational performance, acid-base status, and mineral metabolism of Holstein cows. J. Dairy Sci. 80:1207-1216.

SAS Institute. 2001. SAS User's Guide. Statistics, Version 8 ed. SAS Inst., Inc., Cary, NC.

Schneider, P. L., D. K. Beede, and C. J. Wilcox. 1988. Nycterohemeral patterns of acid-base status, mineral concentrations and digestive function of lactating cows in natural or chamber heat stress environments. J. Anim. Sci. 66:112-125.

Stokes, M. R., L. L. Vandemark, and L. S. Bull. 1986. Effects of sodium bicarbonate, magnesium oxide, and a commercial buffer mixture in early lactation cows fed hay crop silage. J. Dairy Sci. 69:1595-1603.

Tucker, W. B., G. A. Harrison, and R. W. Hemken. 1988a. Influence of dietary cation-anion balance on milk, blood, urine and rumen fluid in lactating dairy cattle. J. Dairy Sci. 71:346-354.

Tucker, W. B., and J. F. Hogue. 1990. Influence of sodium chloride or potassium chloride on systemic acid-base status, milk yield and mineral metabolism in lactating dairy cows. J. Dairy Sci. 73:3485-3493

Tucker, W. B., J. F. Hogue, D. F. Waterman, T. S. Swenson, Z. Xin, R. W. Hemken, J. A. Jackson, G. D. Adams, and L. J. Spicer. 1991. 
Role of sulfur and chloride in the dietary cation-anion balance equation for lactating dairy cattle. J. Anim. Sci. 69:1205-1213.

Tucker, W. B., Z. Xin, and R. W. Hemken. 1988b. Influence of dietary calcium chloride on adaptive changes in acid-base status and mineral metabolism in lactating dairy cows fed a diet high in sodium bicarbonate. J. Dairy Sci. 71:1587-1597.

Van Soest, P. J., J. B. Robertson, and B. A. Lewis. 1991. Methods for dietary fiber, neutral detergent fiber, and nonstarch polysac- charides in relation to animal nutrition. J. Dairy Sci. 74:35833597.

West, J. W., K. D. Haydon, B. G. Mullinix, and T. G. Sandifer. 1992. Dietary cation-anion balance and cation source effects on production and acid-base status of heat-stressed cows. J. Dairy Sci. 75:2776-2786.

West, J. W., B. G. Mullinix, and T. G. Sandifer. 1991. Changing dietary electrolyte balance for dairy cows in cool and hot environments. J. Dairy Sci. 74:1662-1674. 